\title{
GAYA KEPEMIMPINAN PADA PT PANCARAN LOGISTIK INDONESIA
}

\author{
NUR KHOLIFAH \\ nurkholifah553@gmail.com \\ ARIO BAGUS APRILIYAN \\ ariobagusapriliyan@yahoo.com \\ Mahasiswa Fakultas Ekonomi dan Bisnis Universitas narotama
}

\begin{abstract}
ABSTRAK
Tujuan dari studi ini adalah untuk mengetahui gaya kepemimpinan yang dilakukan atau diterapkan oleh direktur kepemimpinan PT Pancaran Logistik Indonesia dengan menggunakan 3 jenis gaya kepemimpinan yaitu: Gaya kepemimpinan otokratis, gaya kepemimpinan demokratis, dan gaya kepemimpinan kendali bebas. Jenis penelitian yang dilakukan adalah penelitian kualitatif. Obyek yang diteliti adalah gaya kepemimpinan pada PT Pancaran Logistik Indonesia.
\end{abstract}

Kata kunci; Gaya kepemimpinan, Gaya otokratis, Gaya Partisipatif, Gaya Delegatif.

\section{PENDAHULUAN}

\subsection{Latar Belakang}

Sebuah perusahaan selalu menginginkan pemimpin yang handal dalam menghadapi perkembangan bisnis usaha dan karyawan. Dituntut untuk menjaga keberlangsungan perusahaan. salah satu cara perusahaan mempertahankan keberlangsungan perusahaan yaitu dengan mengoptimalkan sumber daya manusia. Mengoptimalkan sumber daya manusia dengan memberikan motivasi dan dorongan kepada karyawan atau pengikut terkait dengan hal kepemimpinan, bagaimana cara seorang pemimpin harus dapat menerapkan gaya kepemimpinan yang dapat mendorong dan menggerakan karyawan agar karyawan tersebut dapat bekerja dengan efektif dan efisien dalam mencapai tujuan organisasi. Sebagai contoh bukti nyata seperti yang dirasakan warga Jakarta atas gaya kepemimpinan yang diterapkan Ahok, yaitu tegas dan berani dalam mengambil keputusan. Namun itu semua tidak membuat warga Jakarta mengurangi rasa optimisnya kepada Ahok. Hal ini di buktikan dari hasil survey Populi Center yang mengatakan bahwa masyarakat Jakarta sebagian besar mengatakan puas dengan kepemimpinan ahok dan mengatakan Jakarta mengalami kemajuan, namun ada juga sebagian kecil yang merasa tidak puas dengan kepemimpinan ahok dan mengatakan Jakarta tidak mengalami perubahan ataupun peningkatan. Jadi dapat disimpulkan bahwa gaya kepemimpinan yang diterapkan pemimpin dapat mempengaruhi keberhasilan sebuah organisasi. Seperti bagaimana cara pemimpin menjalin hubungan dengan bawahan, bagaimana cara seorang pemimpin memerlakukan bawahan dan cara 
pemimpin mempengaruhi perilaku bawahan. Tidak sedikit kegagalan perusahaan disebabkan karena gaya kepemimpinan yang salah.

Sebagai salah satu perusahaan yang bergerak dibidang warehouse dan distributor Elektronik Samsung fenomena yang terjadi yaitu karyawan yang bekerja tidak baik, malasmalasan, tidak mematuhi perintah atau susah diberi arahan dan karyawan yang bekerja seenaknya sendiri ketika tidak di awasi, dari fenomena yang terjadi dapat disimpulkan bahwa gaya kepemimpinan pemimpin yang diterapkan di PT Pancaran Logistik Indonesia tidak berjalan sebagaimana mestinya atau tidak berjalan dengan efektif. Karena salah satu faktor penting untuk mengoptimalkan kinerja karyawan yaitu gaya kepemimpinan yang diterapkan pemimpin, dalam suatu organisasi pemimpin memiliki pengaruh besar dalam kepentingan perusahaan atau organisasi untuk mencapai tujuan, dan seorang pemimpin harus memaksimalkan sumber daya yang dimiliki.

Sumber daya manusia merupakan faktor penting dalam perusahaan, bukan hanya faktor pelengkap. Yang artinya pemimpin harus menerapkan gaya kepemimpinan yang tepat agar dapat mendorong, menggerakan, memotivasi dan mempengaruhi karyawan sehingga dapat bekerja dengan efektif dan efisien untuk mencapai tujuan organisasi. Oleh karena itu, diperlukan penelitian secara deskriptif mengenai gaya kepemimpinan yang diterapkan oleh pemimpin pada PT Pancaran Logistik Indonesia. Apa yang sebaiknya mereka ketahui tentang kepemimpinan mereka dalam menjalankan perusahaan. Hal ini menjadi hal yang sangat penting dan bermanfaat bagi PT Pancaran Logistik Indonesia untuk dapat menjalankan kepemimpinan dalam mengoptimalkan sumber daya manusianya, sebab sumber daya manusia merupakan salah satu faktor penting dalam keunggulan kompetitif perusahaan sehingga tujuan organisasi dapat tercapai.

\subsection{Rumusan Masalah}

Bagaimana gaya kepemimpinan direktur yang diterapkan di PT Pancaran Logistik Indonesia.

\subsection{Tujuan Masalah}

Melakukan penelitian ini yaitu mengidentifikasikan dan menganalisis gaya kepemimpinan direktur di PT Pancaran Logistik Indonesia.

\section{TINJAUAN PUSTAKA}

Dalam kehidupan sehari-hari kita selalu dihadapkan dengan istilah organisasi Organisasi bisnis biasanya bertujuan untuk mencari keuntungan finansial, organisasi kemasyarakatan biasanya bertujuan untuk tujuan kemasyarakatan, organisasi politik biasanya untuk tujuan kekuasaan dan organisasi keagamaan biasanya untuk tujuan misi atau dakwah.Tujuan tersebut menurut AsakuWalisongo (2013) dicerminkan oleh sasaran yang harus dilakukan baik dalam jangka pendek, maupun jangka panjang.Implementasinya setiap organisasi merumuskan visi, misi, serta tujuan baik jangka pendek, menengah maupun jangka panjang. Setiap organisasi tentu memiliki pemimpin dan kepemimpinan.Biasanya pemimpin memiliki pengaruh lebih besar dalam upaya pencapaian tujuan organisasi, oleh karena pemimpin sering diistilahkan dengan orang yang mempengaruhi bawahan untuk mencapai tujuan yang diharapakan. Pendapat itu sejalan dengan yang disampaikan olehHusaini Usman (2013 : 312), kepemimpinan ialah ilmu dan seni 
mempengaruhi, orang atau kelompok untuk bertindak seperti yang diharapkan untuk mencapai tujuan secara efektif dan efisien. Jadi jelas bahwa pemimpin memiliki pengaruh besar terhadap sukses tidaknya sebuah oraganisasi. Salah satu fungsi yang harus dilakukan pemimpin dalam upaya pencapaian tujuan adalah bagaimana pemimpin itu bisa mengambil keputusan dengan efektif.Dalam realita pengambilan keputusan bukanlah hal yang sedernana, sebab setiap pengambilan keputusan biasanya mengandung dua konsekuensi sekaligus baik konsekuensi positif maupun konsekuensi negatif. Namun demikian seorang pemimpin harus berani mengambil keputusan dari beberapa pilihan yang dihadapai. Seorang pemimpin diharapkan mengikuti pendapat Terry dalam Marzuki (2015 : 2), bahwa dalam mengambil keputusan hendaklah memilih yang terbaik dari berbagai altenatif yang tersedia. Salah satu tugas terpenting seorang pemimpin adalah untuk menentukan yang terbaik bagi organisasi dan para anggotanya.Namun dalam mengambil keputusan, terkadang pemimpin pun menghadapi dilema dan seolah berada di persimpangan jalan. Kecepatan dan ketepatan seorang pemimpin dalam mengambil keputusan lazimnya menjadi tolak ukur kompetensi dan kredibilitas yang dimilikinya. Jika pemimpin lamban dan ragu-ragu dalam bertindak, anak buah akan melihat bahwa pemimpin tersebut adalah pemimpin yang tidak berani mengambil resiko. Terbiasa cepat dalam pengambilan keputusan memang bukan pekerjaan mudah, butuh rasio yang jernih dan intuisi yang tajam agar bisa menghasilkan keputusan yang tepat.Menarik untuk dikaji bagaimana seorang pemimpin bisa mengambil keputusan dengan baik, dalam pengertian efektif, efisien, meminimalkan resiko, serta bermanfaat bagi kemajuan organisasi dalam rangka pencapaian tujuan yang diharapkan.

\section{METODE PENELITIAN}

Jenis penelitian ini merupakan penelitian kualitatif, penelitian kualitatif adalah metode penelitian yang berlandaskan pada filsafat postpositivisme, digunakan untuk meneliti pada kondisi objek yang alamiah, dimana peneliti adalah sebagai instrumen kunci, pengambilan sampel sumber data dilakukan secara purposive dan snowball, teknik pengumpulan dengan trianggulasi (gabungan), analisis data bersifat induktif (Sugiyono, 2012, p.14).Salah satu ciri penelitian kualitatif adalah deskriptif.Ciri dari deskriptif yaitu data yang dikumpulkan adalah berupa katakata, gambar dan bukan angka-angka. Penelitian ini menggunakan kualitatif deskriptif karena penulis menggambarkan kondisi apa yang terjadi pada PT Pancaran Logistik Indonesia khususnya dalam gaya kepemimpinan pemimpinnya. Metode pengumpulan data dalam penelitian ini dilakukan melalui wawancara dan dokumen. Wawancara menurut esterberg (2002) adalah pertemuan dua orang untuk bertukar informasi dan ide melalui tanya jawab, sehingga dapat dikonstruksikan makna dalam suatu topik tertentu (dalam Sugiyono, 2012, p.410).

Jenis wawancara yang digunakan adalah wawancara semistruktur. Wawancara ini termasuk dalam kategori in-dept interview karena dalam pelaksanaannya lebih bebas bila dibandingkan dengan wawancara terstruktur. Tujuan dari jenis wawancara ini adalah untuk menemukan permasalahan secara lebih terbuka dengan meminta pihak yang diwawancara untuk memberikan pendapat dan ide-idenya (Sugiyono, 2012, p.413). Tujuan penggunaan wawancara semiterstruktur ini adalah untuk menemukan permasalahan yang lebih terbuka agar dapat menggali data lebih mendalam dimana pihak yang diwawancarai juga diminta pendapat atau ide-idenya, 
sehingga penulis akan mendengarkan secara teliti dan seksama apa yang dikemukakan oleh narasumber..Metode penelitian kedua adalah dokumentasi, dimana peneliti menggunakan dokumen-dokumen yang merupakan catatan peristiwa yang telah berlalu. Dokumen yang akan digunakan dalam penelitian ini antara lain adalah struktur organisasi, job description, dan dokumentasi proses operasional perusahaan.

\section{PEMBAHASAN}

Visi dan misi perusahaan merupakan penjelasan dari cita-cita yang hendak dicapai oleh perusahaan di dalam menjalankan aktivitasnya. Secara umum visi PT Pancaran Logistik Indonesia yaitu menjadi perusahaan yang terdepan dan termaju, sedangkan misi PT Pancaran Logistik Indonesia yaitu memberikan pelayanan terbaik untuk kepuasan pelanggan. Hasil penelitian ini didapatkan dari hasil wawancara data pada direktur PT Pancaran Logistik Indonesia dan kedua informan lainnya, Tujuan wawancara ini adalah untuk menggali informasi tentang gaya kepemimpinan direktur PT Pancaran Logistik Indonesia, berikut hasil wawancara dari masingmasing informan berdasarkan indikator yang ada :

\section{Mengenai pendelegasian wewenang}

- Direktur

Berdasarkan uraian pekerjaan, jabatan manajer biasa ditugaskan menggantikan presentasi ketika sedang ada urusan diluar kota, jika ada rapat biasa ditugaskan menggantikan memimpin rapatnya, dan direktur memberi wewenang seperti menegur karyawan apabila ada karyawan yang malasmalasan, tidak disiplin dan melakukan kesalahan. Jika untuk jabatan manajer logistic diberi wewenang sesuai kondisi yang ada digudang, seperti menegur karyawan yang malasmalasan, ditugaskan memberi laporan mengenai stok barang, pengiriman maupun penerimaan barang, melaporkan kepada direktur apabila ada karyawan yang melakukan kesalahan berat, seperti ketahuan mencuri barang atau yang lain.

- Manajer Operasional dan Administrasi

Mengenai pendelegasian wewenang yang diterapkan direktur di PT Pancaran Logistik Indonesia, manajer administrasi dan operasional diperintahkan menggantikan memimpin rapat, presentasi, menegur karyawan yang tidak disiplin, malas-malasan dalam bekerja seperti main game, ngobrolngobrol dan memberikan surat peringatan pada karyawan yang melakukan kesalahan yang tergolong berat.

- Kepala Bagian Logistik

Mengenai pendelegasian wewenang yang diterapkan direktur di PT Pancaran Logistik Indonesia, kepala bagian di berikan wewenang seperti menegur karyawan yang malas-malasan saat bekerja, melakukan kesalahan sederhana namun berulang kali dan apabila kesalahan berat akan dilaporkan ke direktur, kesalahan berat yang dimaksudkan yaitu seperti ketahuan mencuri barang maka harus langsung dilaporkan kedirektur.

2. Pengambilan Keputusan dan Kebijakan 
- Direktur

Mengenai pengambilan keputusan dan kebijakan yaitu dengan mendengarkan saran, kritik dari karyawan untuk menjadi pertimbangan, dan akan mendiskusikan dahulu ada kritik dan saran dari karyawan yang dapat membantu dalam menentukan keputusan itu. Biasa melalui rapat atau perdebatan untuk mencari solusinya.

- Manajer Operasional dan Administrasi

Mengenai pengambilan keputusan dan kebijakan direktur mendengarkan kritik dan saran dari manajer operasional dan aministrasi dahulu untuk menjadi pertimbangan melalui rapat dan perdebatan sampai menemukan solusi.

- Kepala Bagian Logistik

Mengenai pengambilan keputusan dan kebijakan direktur biasa mendengarkan keluhan-keluhan dari karyawan dahulu, lalu meminta untuk memberikan saran, ide atau pendapatnya untuk dijadikan bahan pertimbangan dalam mengambil keputusan atau mencari solusi terbaik.Namun semua keputusan tetap dibuat atau ditentukan oleh direktur sendiri.

\section{Sifat Pemimpin}

- Direktur

Mengenai pandangan pemimpin direktur ingin menjadi sosok pemimpin yang tegas, bijaksana dan berwibawa. Karena disini direktur menjadi pemimpin dan direktur ingin semua karyawan menghormati direktur, namun bukan berarti karyawan takut, melainkan karyawan akan menghormati dan menghargai keputusan-keputusan yang telah ditentukan. Sedangkan upaya direktur untuk membuat karyawan menjadi loyal yaitu membuat grup sosial media supaya dapat berkomunikasi dengan semua karyawan dan saat bulan puasa mengadakan acara makan bersama saat buka agar karyawan merasa nyaman dan lebih akrab satu dengan yang lain.

- Manajer Operasional dan Administrasi

Mengenai pandangan pemimpin direktur merupakan sosok yang bijaksana, tegas dan beribawa.Tegas terutama dalam menentukan keputusan, jika keputusan sudah dibuat atau ditentukan maka tidak bisa dirubah lagi. Direktur juga membuat grup chat di media sosial, agar memudahkan berkomunikasi pada semua karyawan, terkadang dibulan puasa juga ada makan bersama, biasa juga setelah jam kerja ada makan-makan bersama kesuatu tempat. Bertujuan agar kita satu dengan yang lain lebih akrab dan lebih mengenali satu dengan yang lain untuk memudahkan kita dalam bekerjasama.

- Kepala Bagian Logistik

Mengenai pandangan pemimpin direktur merupakan sosok yang bijaksana, tegas dan beribawa.Tegas terutama dalam menentukan keputusan, jika keputusan sudah dibuat atau ditentukan maka tidak bisa dirubah lagi. Direktur juga membuat grup chat di media sosial, agar memudahkan berkomunikasi pada semua karyawan, terkadang dibulan puasa juga ada makan 
bersama, biasa juga setelah jam kerja ada makan-makan bersama kesuatu tempat. Bertujuan agar kita satu dengan yang lain lebih akrab dan lebih mengenali satu dengan yang lain untuk memudahkan kita dalam bekerjasama.

4. Pengarahan Bawahan

- Direktur

Mengenai pengarahan bawahan direktur selalu meminta kepada semua karyawan untuk disiplin dalam segala hal, seperti dalam hal memberikan laporan dan jam kerja lalu juga harus disiplin dalam hal menaati peraturan-peraturan yang telah ditetapkan oleh perusahaan karena dengan disiplin perusahaan baru bisa maju, direktur juga akan menegur setiap karyawan membuat kesalahan, memperingatkan agar tidak terulang kembali, dan memberi surat peringatan bagi yang melakukan kesalahan berat. Serta ada pengawasan yang dilakukan yaitu dengan cara memeriksa laporan tiap karyawan.

- Manajer Operasional dan Administrasi

Sedangkan mengenai pengarahan bawahan direktur selalu meminta untuk terus mencari terobosanterobosan baru dan disiplin, disiplin dalam menaati peraturanperaturan kantor yang telah ditetapkan oleh perusahaan dan juga disiplin dalam mengerjakan atau membuat laporan karena setiap harinya selalu akan diminta hasil laporan pekerjaan, juga selalu mengingatkan supaya setiap kesalahan-kesalahan mendasar tidak terulang lagi, dan apabila kesalahanya berat diberikan surat peringatan atau teguran keras. Sedangkan pengawasan yang dilakukan direktur yaitu dengan selalu meminta laporan untuk mengetahui perkembangan perusahaan.

- Kepala Bagian Logistik

Sedangkan mengenai pengarahan bawahan direktur selalu memberi motivasi seperti bekerja dengan disiplin, disiplin dalam menaati peraturan-peraturan yang telah ditetapkan perusahaan maupun disiplin dalam mengerjakan laporan agar tepat waktu karena setiap harinya akan di cek hasil laporan pengiriman maupun penerimaan barang untuk mengetahui perkembangan dan direktur selalu mengingatkan supaya setiap masalahmasalah kecil yang mendasar tidak terulang lagi, bisa diberi teguran keras apabila kesalahan yang sama terulang terus dan juga jika kesalahan berat maka bisa dipecat.

Pembahasan didapatkan dari hasil analisis data pada direktur PT Pancaran Logistik Indonesia dan kedua informan lainnya, peneliti menganalisis bahwa gaya kepemimpinan direktur yang diterapkan di PT Pancaran Logistik Indonesia berdasarkan indikator yang ada yaitu pendelegasian wewenang, pengambilan keputusan dan kebijakan, sifat pemimpin dan pengarahan bawahan.

1. Pendelegasian wewenang.

Menurut Hasibuan (2012, p.170) dalam hal pendelegasian wewenang gaya kepemimpinan otoriter yaitu kekuasaan atau wewenang mutlak tetap berada pada pimpinan. Pimpinan itu menganut sistem sentralisasi wewenang. Hal ini sama dengan yang dibilangkan dijurnal Gede Bayu Surya Parwita yang berjudul kepemimpinan dalam organisasi kepemudaan 
karang taruna manggala kelurahan sesetan yang mengatakan bahwa dalam pendelegasian wewenang gaya kepemimpinan otoriter merupakan tindakan pemimpin menurut kemauan sendiri. Perintah hanya dari satu pihak saja, tidak boleh dibantah dan semua kebijakan ditentukan pemimpin. Sedangkan gaya kepemimpinan partisipatif dalam hal pendelegasian wewenang adalah pemimpin menganut sistem manajemen terbuka atau desentralisasi wewenang. Untuk gaya kepemimpinan delegatif dalam hal pendelegasian wewenang yaitu pemimpin mendelegasikan wewenang kepada bawahan dengan lengkap atau semua diserahkan

bawahan. Dengan demikian, bawahan dapat mengambil keputusan dan kebijaksanaan dengan bebas atau leluasa dalam melaksanakan pekerjaan. Pada PT Pancaran Logistik Indonesia pendelegasian wewenang ditentukan sendiri oleh direktur sebagai pemimpin seperti direktur memberikan wewenang ke karyawan bagian manajer operasional dan administrasi seperti menggantikan rapat dan menggantikan presentasi ketika direktur sedang ada urusan lain diluar kota. Sebagai bukti lain manajer operasional, administrasi dan kepala bagian logistik juga menyatakan bahwa direktur yang menentukan pendelegasian wewenang, dan tanggung jawab yang diberikan direktur kepada karyawan berdasarkan posisi jabatan karyawan. Misalnya semakin tinggi posisi jabatan karyawan, maka wewenang dan tanggung jawab juga semakin besar. Sedangkan untuk kepala bagian logistik diberi wewenang menegur karyawan, dan memberi surat peringatan jika ada yang melakukan kesalahan berat, juga bertanggung jawab atas stok barang digudang, pengiriman maupun penerimaan barang, melaporkan kinerja karyawan digudang pada direktur. Jadi dari hal pendelegasian wewenang menunjukan bahwa direktur di PT Pancaran Logistik Indonesia lebih cenderung menerapkan gaya kepemimpinan Partisipatif karena direktur memberikan wewenang terhadap karyawannya. Dalam hal pendelegasian wewenang ini sama dengan yang ada dipenelitian terdahulu yang mengatakan bahwa pemimpin menerapkan gaya kepemimpinan partisipaf dalam pendelegasian wewenangnya karena pemimpin memberikan wewenang berdasarkan karyawan sesuai dengan pekerjaan atau jabatannya.

2. Pengambilan keputusan dan kebijakan.

Menurut Hasibuan (2012,p.170) dalam hal pengambilan keputusan dan kebijakan gaya kepemimpinan otoriter yaitu mengenai pengambilan keputusan dan kebijaksaan hanya ditetapkan sendiri oleh pemimpin, bawahan tidak diikutsertakan untuk memberikan saran, ide, dan pertimbangan dalam proses pengambilan keputusan. Untuk gaya kepemimpinan partisipatif dalam hal pengambilan keputusan dan kebijakan yaitu bawahan harus berpartisipasi memberikan saran, ide dan pertimbangan dalam proses pengambilan keputusan. Namun berbeda dengan gaya kepemimpinan demokratis yang ada di jurnal gede bayu surya parwita yang berjudul kepemimpinan dalam organisasi kepemudaan karang taruna manggala kelurahan sesetan, yang mengatakan bahwa semua kebijaksanaan terjadi pada kelompok diskusi dan keputusan, dengan bantuan dan dorongan pemimpin, jika dibutuhkan pemimpin akan menyarankan dua alternative atau lebih yang dapat dipilih dalam menentukan keputusan. Namun hal pengambilan keputusan dan kebijakan yang ada di jurnal Surya S yang berjudul Organizational Leadership: A conceptual Analysis 
mengatakan bahwa gaya kepemimpinan partisipatif dalam pengambilan keputusan meliputi diskusi, debat dan berbagai ide dan dorongan dari orangorang. Sedangkan gaya kepemipinan delegatif mengenai pengambilan keputusan dan kebijakan pemimpin tidak peduli cara bawahan mengambil keputusan dan mengerjakan pekerjaanya, sepenuhnya diserahkan kepada bawahan. Keputusan tetap dilakukan pimpinan dengan mempertimbangkan saran atau ide yang diberikan bawahannya.Direktur mengatakan bahwa pengambilan keputusan dari setiap masalah yang terjadi di PT Pancaran Logistik Indonesia direktur sebagai pemimpin selalu meminta ide, saran atau pendapat dari karyawan untuk menjadi bahan pertimbangan dalam mengambil keputusan.Namun keputusan terakir tetap ditentukan oleh direktur sendiri sebagai pemimpin. Sebagai bukti lain yaitu manajer operasional dan administrasi, dan kepala bagian logistic mengatakan bahwa direktur di PT Pancaran Logistik Indonesia dalam hal pengambilan keputusan meminta saran, pendapat atau ide terlebih dahulu sebagai bahan pertimbangan sebelum menentukan keputusan yaitu dilakukan melalui rapat. Manajer operasional dan logistic maupun kepalaga bagian logistik juga mengatakan bahwa ide, saran atau pendapat hanya untuk bahan pertimbangan, mengenai keputusan terakhir tetap ditangan direktur. Jadi dalam hal pengambilan keputusan maka gaya kepemimpinan yang diterapkan direktur di PT Pancaran Logistik Indonesia cenderung ke gaya kepemimpinan partisipatif karena direktur selalu meminta saran, idea tau pendapat dahulu dari bawahan. Dalam hal pengambilan keputusan dan kebijakan ini sama dengan yang di katakan di jurnal Mukhamad Fathoni, Suryadi, Stefanus Pani Rengu yang berjudul gaya kepemimpinan kepala desa dalam pembangunan fisik desa, yang mengatakan bahwa gaya kepemimpinan kepala desa Denok yaitu demokratis atau sama dengan partisipatif. Hal itu terbukti karena di dalam pengambilan keputusan serta pengawasan selalu melibatkan masyarakat desa di dalam proses tersebut dan mau menerima kritik dan saran dari masyarakat desa Osowilangon.

\section{Sifat pemimpin.}

Menurut Hasibuan (2012,p.170) dalam hal pandangan pemimpin gaya kepemimpinan otoriter mengenai pandangan pemimpin yaitu pemimpin menganggap dirinya yang paling berkuasa dan paling pintar. Untuk gaya kepemimpinan partisipatif mengenai pandangan pemimpin ialah apabila dalam kepemimpinanya dilakukan dengan cara persuasive, menciptakan kerjasama yang serasi, menumbuhkan loyalitas, dan partisipatif para bawahanya. Sedangkan untuk gaya kepemimpinan delegatif mengenai pandangan pemimpin pimpinan tidak akan membuat peraturan-peraturan tentang pelaksanaan pekerjaan itu, dan hanya sedikit melakukan kontak dengan bawahannya. Direktur sebagai pemimpin perusahaan selalu melakukan komunikasi dengan karyawan pada jam kerja maupun diluar jam kerja bertujuan untuk lebih mengakrabkan hubungannya dengan bawahan, dengan cara membuat grup chat dimedia sosial sehingga makin kita akrab lebih mudah untuk bekerjasama dan karyawanpun juga lebih nyaman dalam bekerja dan terkadang Edison juga mengadakan buka bersama saat bulan puasa. Dari berberapa hal yang dilakukan direktur akan membuat hubungan antara direktur dan karyawan lebih akrab, otomatis terciptanya kerjasama yang lebih serasi dan juga akan timbul loyalitas dari 
karyawan. Sebagai bukti lain hal tersrbut juga dikatakan oleh manajer operasional, administrasi dan kepala bagian logistik bahwa Edison selalu mengadakan acara makan bersama setelah jam kerja, mengadakan buka bersama saat bulan puasa, dan sering melakukan komunikasi-komunikasi pada saat jam kerja maupun diluar jam kerja. Jadi dalam hal pandangan pemimpin direktur di PT Pancaran Logistik Indonesia lebih cenderung menerpakan gaya kepemimpinan partisipatif.

4. Pengarahan bawahan

Menurut Hasibuan (2012, p.170) dalam hal pengarahan bawahan gaya kepemimpinan otoriter adalah pengarahan bawahan dilakukan dengan memberikan intruksi atau perintah, ancaman hukuman, serta pengawasan dilakukan secara ketat. Dalam hal pengarahan bawahan gaya kepemimpinan otoriter ini sama dengan yang ada di penelitian terdahulu dalam jurnal yang dibuat oleh Surya S, dengan judul Organizational Leadership: A conceptual Analysis yang mengatakan bahwa gaya kepemimpinan otoriter dalam hal pengarahan bawahan pemimpin otokratis terus ketat, kontrol ketat atas para pengikutnya dengan menjaga regulasi dekat kebijakan dan prosedur yang diberikan kepada pengikut pengawasan langsung apa yang mereka yakini sebagai kunci dalam menjaga lingkungan yang sukses. Untuk gaya kepemimpinan partisipatif mengenai pengarahan bawahan yaitu Pemimpin akan selalu membina bawahan untuk menerima tanggung jawab yang lebih besar. Sedangkan untuk gaya kepemimpinan delegatif dalam hal pengarahan bawahan yaitu bawahan dituntut untuk memiliki kematangan pekerjaan dan psikologis. Direktur sebagai pemimpin selalu melakukan pengawasan kepada karyawanya seperti meminta laporan sewaktu-waktu untuk melihat perkembangan pengerjaan setiap harinya.Direktur juga menginstruksikan karyawan agar bekerja dengan disiplin, karena menurut direktur disiplin dapat membuat perusahaan menjadi maju.Setiap karyawan juga diwajibkan untuk menaati peraturan-peraturan yang telah ditetapkan perusahaan. Peraturan-peraturan yang dimaksudkan ada dihalaman 29 sub bab 4.1.4. Direktur juga tegas dalam memberikan hukuman berupa teguran jika kesalahan yang tergolong ringan, dan surat peringatan jika kesalahannya tergolong berat yang nantinya juga akan berdampak ke pemecatan ketika karyawan telah mendapat surat peringatan lebih dari dua kali. Sebagai bukti lain yaitu manajer operasional dan administrasi serta kepala bagian logistik juga mengatakan bahwa dalam hal pengarahan bawahan direktur selalu meminta kita untuk disiplin dalam memberi laporan, dalam hal jam kerja, dan selalu diminta untuk menaati peraturan-peraturan yang ditetapkan oleh perusahaan. Karena pengawasan yang dilakukan direktur seperti meminta laporan untuk mengetahui perkembangan perusahaan. Untuk kepala bagian logistik bertujuan untuk mengetahui perkembangan digudang serta transportasi. Selain itu direktur juga meminta manajer operasional dan administrasi untuk mencari terobosan-terobosan baru dan selalu mengingatkan agar tidak melakukan kesalahankesalahan yang tergolong mendasar, atau kesalahan yang sama terjadi berulang kali. Sedangkan untuk kepala bagian logistik juga diminta untuk disiplin dan tepat waktu dalam hal memberi laporan terkait pengiriman dan penerimaan barang digudang, dan juga diminta untuk tidak melakukan kesalahan-kesalahan yang menjadi aturan kantor, atau mengulang kesalahan yang sama. 
Jadi dalam hal pengarahan bawahan direktur di PT Pancaran Logistik Indonesia cengderung menerapkan gaya kepemimpinan otoriter.

\section{KESIMPULAN}

Gaya Kepemimpinan direktur, termasuk gaya kepemimpinan partisipatif dalam hal pendelegasian wewenang, hal ini terbukti karena direktur memberikan wewenang dan tanggung jawab kepada karyawan, namun wewenang dan tanggung jawab yang diberikan juga berdasarkan jabatan. Dalam hal pengambilan keputusan dan kebijakan direktur termasuk gaya kepemimpinan partisipatif, terbukti karena setiap pengambilan keputusan dan kebijakan yang dilakukan direktur, selalu melibatkan saran, ide atau pendapat dari karyawan. Sifat pemimpin perusahaan, lebih ke gaya kepemimpinan partisipatif terbukti direktur selalu ingin menumbuhkan rasa loyal setiap karyawannya, lalu ada berberapa upaya yang dilakukan yang bertujuan agar karyawan juga makin akrab dan nyaman dalam bekerjasama. Pemimpin menerapkan gaya kepemimpinan otoriter dalam hal pengarahan bawahan, terbukti bahwa direktur selalu memberikan perintah atau instruksi kepada bawahan agar disiplin, dan direktur juga memberikan hukuman apabila ada karyawan yang melanggar aturan.

\section{DAFTAR PUSTAKA}

Alimudin, Arasy, and Agus Sukoco. "The Leadership Style Model That Builds Work Behavior Through Organizational Culture." JURNAL LENTERA: Kajian Keagamaan, Keilmuan Dan Teknologi 3.2 (2017): 362-375.

Bambale, A.J. (2011). Auditing the Leadership Approaches and Their Relationsships to Organizational Outcomes. Journal Business and Management Review Vol. 1(2) pp. 01 - 13. Retrieved April 12, 2016, from http://www.businessjournalz.org/articlepdf/BMR_1204. Pdf

Bungin, B. (2003). Analisis Data Penulisan Kualitatif: Pemahaman Filosofis dan Metodologis ke Arah Penguasaan Model Aplikasi. Jakarta : Rajawali Pers.

Fathoni M., Suryadi., Rengu, S.P. (2015). Gaya Kepemimpinan Kepala Desa dalam Pembangunan Fisik Desa. Jurnal Administrasi Publik; Vol.3, No.1. Retrieved April 12, 2016 from http://administrasipublik.studentjournal.ub.ac.id/index.php/jap/article/view/659

Harun, H., \& Salleh, N.N.H.M. (2014). Students' Perception of the Leadership Style of Lecturers in Vocational College. Journal of Education and Practice ; Vol.5,No.23. Retrieved April 12, 2016 from http://iiste.org/Journals/index.php/JEP/article/viewFile/15228/15595

Hasibuan, S.P. (2012). Manajemen Sumber Daya Manusia (Edisi Revisi). Jakarta: PT. Bumi Aksara.

Hidayati (2012). Analisis Gaya Kepemimpinan Rusli Zainal Sebagai Kepala Pemerintahan Provinsi Riau. Jurnal Kajian Ilmu Pemerintahan ; Vol.1, No.1. Retrieved May 25, 2016 from http://rat.uir.ac.id/index.php/JKP/article/view/303 
Irawanto, D.W. (2008). Kepemimpinan : Esensi dan Realitas. Malang: Bayumedia.

Moleong, L. J. (2013). Metode penelitian kualitatif (Edisi revisi). Bandung : Remaja Rosdakarya.

Mulyadi, D. (2015). Perilaku organisasi dan kepemimpinan pelayanan. Bandung : Alfabeta.

Ojo, L.I., \& Ojo, B.B. (2012). Effective Leadership: Tool for Achieving Political Stability and National Development in Nigeria. Journal of Education and Practice ; Vol.3,No.2. Retrieved May 25, 2016 from http://pakacademicsearch.com/pdffiles/edu/413/716\%20Vol\%203,\%20No\%202\%20(2012).p df

Robbins, S.P., \& Coulter, Mary, (2002), Management. New jersey : Prentice hall

Robbins, S.P., \& Judge, T.A. (2011). Organizational Behavior (14th ed). New Jersey: Pearson.

Robbins, S.P. (2005). Organizational Behavior : Instructor's resource (11th ed). New Jersey:Pearson Education Asia.

Sugiyono. (2012). Metode Penelitian Bisnis: Pendekatan Kuantitatif, Kualitatif (R\&D). Bandung: Alfabeta.

Surya, S. (2015). Organizational Leadership : A conceptual analysis. International Journal of Organizational Behaviour \& Management Perspectives; Vol.4, No. 3. Retrieved May 25, 2016 from

http://pezzottaitejournals.net/pezzottaite/images/ISSUES/V4N2/IJOBMPV4N219.pdf

Thoha, M. (2007). Perilaku Organisasi: Konsep Dasar dan Aplikasinya. Jakarta: PT. Raja Grafindo Persada.

Tumbol, C.L., Tewal, B., \& Sepang, J.L. Gaya kepemimpinan otokratis, demokratik dan laissez-faire terhadap peningkatan prestasi kerja karyawan pada KPP pratama manado. Jurnal Emba. Vol. 2, No.1. Retrieved May 25, 2016. From http://download.portalgaruda.org/article.php?article=139321\&val=1025

Umam, K. (2010). Perilaku Organisasi. Bandung: Pustaka Setia.

Wibowo, (2015). Perilaku Dalam Organisasi. Jakarta : Rajawali Pers.

Yulk, G. (2006). Leadership in organization(6th ed). New Jersey: Pearson Education. 